\title{
Learning to publish in English: How can French researchers bridge the gap?
}

Ray Cooke

\section{OpenEdition}

\section{Journals}

Electronic version

URL: http://journals.openedition.org/asp/4394

DOI: $10.4000 /$ asp.4394

ISSN: 2108-6354

\section{Publisher}

Groupe d'étude et de recherche en anglais de spécialité

\section{Printed version}

Date of publication: 1 March 1993

Number of pages: $463-474$

ISSN: 1246-8185

\section{Electronic reference}

Ray Cooke, "Learning to publish in English: How can French researchers bridge the gap? », ASp [Online], 1 | 1993, Online since 03 June 2014, connection on 19 April 2019. URL : http:// journals.openedition.org/asp/4394; DOI : 10.4000/asp.4394

This text was automatically generated on 19 April 2019

Tous droits réservés 


\title{
Learning to publish in English: How can French researchers bridge the gap?
}

\author{
Ray Cooke
}

1 Some of us are now asked to provide editorial assistance for colleagues whose reputation depends on getting their research published in English. I would suggest that if this present trend continues, and no doubt it will, more and more of us will become involved in this activity. It is not without a range of pitfalls to be avoided if working together is to be an efficient rewarding experience. For example, the researcher unaware of what text editing requires, let alone full translation, may contact you on a Monday afternoon saying he has partially written in English a text to be delivered at a forthcoming international congress. When you ask when the congress will be taking place, he replies "On Thursday" and expresses a mixture of surprise, consternation and irritation when you mention that he might have come to you a good week beforehand. For him, you are an English teacher so the job is an easy one.

The following points are developed in this paper:

2 Learning to publish in English - By this I mean getting the text to a sufficiently acceptable level of expression that it meets the requirements of what might loosely be termed the "good communication practice" of scientific and technical English. I do not mean developing oral skills, although the two are clearly interconnected.

French researchers - By this I mean fully-fledged researchers accustomed to reading the English of their own discourse community. I do not mean Ph. D. students who have just left the reassuring cocoon of a world in which information is gleaned from textbooks and manuals written in French, and who would now like to reinforce their curriculum vitae, so why not start straightaway in English?

Bridge the gap - To my mind, the gap is what separates native and non-native speakers in the area of written communication: i.e., the ability, above and beyond the scientific quality of one's work, to gain access to the Anglophone discourse community's written 
genres. I do not mean designing the universal syllabus whose lofty aim is to take researchers of all kinds to a point of autonomy in the production of written English.

At this point it would be as well to briefly go over the process involved in getting a written document published.

There may be several genres: for example, there are case reports, research articles, letters to the editor, correspondence of various sorts, and full chapters of a book, to mention only a few. While some require less grammatical and structural precision, (for example, semi-formal letter to a colleague), others demand varying degrees of finesse. Although a whole chapter for a book must of course contain as few linguistic errors as possible, the very nature of the genre makes it something that is fairly easy to get published. After all the author, whose international reputation is probably already well established, will have been asked by an equally well known and respected editor to make a contribution to the latter's forthcoming state of the art manual. The complicity that these two top-ranking people will enjoy means that the editor is prepared to stretch forth a helping hand, and will himself probably undertake any editing required after initial revision by a linguist colleague of the author.

7 However, a research article reporting new and possibly contradictory findings to what was previously believed must go through at least two reviewers and an editor, all members of the same discourse community and frequently native speakers or nearly so; which raises the question of how these people might react to findings which could outdate their own, undermine the very foundations on which their theories, hence reputations, were built, and which might be written in an English open to criticism. I would go as far as to say that such English could in their eyes belie the scientific quality of the work, and at worst could simply be used as a pretext for rejection.

It is clear, then, that in the ironing out of French researchers' English, the stakes are not always the same. What is to be kept in mind here is for whom the piece of writing is destined and what checkpoints have to be gone through on the way. John Swales (1990) refers to "rhetorical awareness", being able to guess how such referees will react to a particular text; and it is this that both French researchers and English language correctors must bear in mind at all times, in order that the latter should help the former to attain "narrow-band proficiency" (Swales 1990) within the genre of his discourse community.

9 For the French researcher to reach his goal of publishing in English, he may use various means which may or may not be at his disposal. These can be broken down into scenarios and corresponding levels of danger (Figure 1).

Figure 1

\begin{tabular}{|l|l|}
\hline SCENARIO & LEVEL OF DANGER \\
\hline 1 No consultation of any sort & GREAT \\
\hline 2 Co-writing, no linguistic help & CONSIDERABLE \\
\hline 3 Editing by non-native speaker linguist & $?$ \\
\hline 4 Editing by native speaker linguist & $?$ \\
\hline
\end{tabular}




\begin{tabular}{|l|l|}
\hline 5 Editing by native speaker subject specialist & MINIMAL \\
\hline 6 Full translation & CONSIDERABLE \\
\hline
\end{tabular}

10 Scenario 1: Here, the researcher, either through ignorance, immaturity or negligence, decides to consult neither specialist colleague nor linguist and simply sends his paper off for review. The danger is great: poorly worded, grammatically incorrect, tautological prose is likely to receive short shrift, even if the scientific content is of some interest.

11 Scenario 2: Here, the team co-writes the text but still seeks no linguistic advice. Scientifically speaking, there is now far less risk of weak argumentation but the English language risk remains.

12 Scenario 3: Here, either one person or the team write the text, which is then shown to a non-native speaker linguist for editing.

13 Scenario 4: This is the same as the former except now the linguist is a native speaker of English.

14 In numbers 3 and 4 the only difference is the oral linguistic competence of the corrector, which even so would apparently be an advantage. So at first sight we might attribute more danger to $n^{\circ} 3$ than to $n^{\circ} 4$. Yet the corrector in $n^{\circ} 3$ would in higher education in France normally be someone well acquainted with the structural components of English, both general and technical, and would stand comparison well with his native speaker counterpart in $n^{\circ} 4$. Indeed, having a native speaker to help is not necessarily a guarantee of success, as a biologist colleague once remarked to me. He had asked the English wife of a banker friend of his to correct an article he had already drafted in English; true, the high-tech terminology was correct - the lady had had nothing to do in this respect - but the whole thing once corrected read like a piece of scientific popularisation.

is the same as $n^{\circ} 4$ except here the native speaker is also a member of that particular discourse community, with the conceptual and linguistic mastery that that entails. This situation must be ideal, with full appropriate support on hand.

In scenario 6, the researcher gives his text in French to a translator or translation agency for full translation. Some researchers might believe this to be the best way of all. Financially costly, true, but time-saving, with the guarantee of receiving a translation that the client himself could never manage. False! Only rarely can a professional translator produce a version of a highly technical research article that, to the members of that discourse community, does not look as though it has been translated.

But this is with certain provisos. When the professional translator possesses sufficient conceptual knowledge of a subject, which itself is the object of a well- codified descriptive process (e.g., "Results" in a medical case study), then the task becomes feasible. However, this is more the exception than the rule. On the other hand, the conceptual knowledge of a subject, i.e., understanding its why and how, is all important in scenarios 3 and 4 , and I would lessen the danger level in both, even place them on the same level, if the corrector possesses such knowledge of the subject he is correcting. To my mind, the ESP teacher in French higher education is capable of such correction providing this precondition is satisfied. 

higher education and its satellite institutions lies in nos. 3 and 4 , what can be done to help bridge the gap. future might or might not lie in research and/or teaching. There are a number of reasons for doing so (Figure 2).

Figure 2: Strategy adopted by researcher and corresponding danger level

\begin{tabular}{|l|l|l|}
\hline Area & Fully-fledged researchers & Students \\
\hline FAMILIARITY WITH DISCOURSE & Yes & Doubtful \\
\hline READING COMPREHENSION SKILLS & Good & Doubtful \\
\hline STRUCTURAL AWARENESS & Good & Doubtful \\
\hline TIME AVAILABLE & Little & FFR \\
\hline USE A PREEXISTING MANUAL? & No & Possible \\
\hline
\end{tabular}

20 First, researchers are already familiar with the schemata and paradigms of their own discourse community and more generally with scientific English as a whole; students may not be.

21 Second, and for this reason, the reading comprehension skills of researchers are frequently superior to those of students, whereas the contrary may be true for basic oral skills. Here, we are concerned with the former.

Third, the corollary of this is greater structural awareness in researchers who are not necessarily used to thumbing through "Instructions to Authors" but at least are aware of their existence; students may not have this awareness.

Fourth, researchers typically have little time to devote to language learning, particularly on a regular extensive basis, while such provision is increasingly being made for students at $\mathrm{Bac}+4 / 5$. So the former need a high surrender nitty-gritty approach giving them maximum yield for minimum investment in time.

Fifth, if researchers are to follow scientific writing courses, how can such programmes be tailored to each individual's needs? The risk is having to review the already known, while bypassing real undisclosed needs. Students, however, can reasonably be expected to use a core method as reference with other support material being grafted on as the need arises.

25 Taken together, these factors point to a set of pedagogic strategies that could be adopted when correcting articles (Figure 3).

Figure 3: Fully fledged researchers and students: differences

\begin{tabular}{|l|l|}
\hline 1 & 1 -TO-1 BASIS \\
\hline 2 & FIRST TIME... NOT TOO MUCH COMMENT \\
\hline
\end{tabular}


\begin{tabular}{|l|l|}
3 & WRITE DOWN LANGUAGE FEATURES \\
\hline 4 & 'INSTRUCTIONS TO AUTHORS' + PUBLISHED ARTICLES
\end{tabular} later, the corrector could draw attention to errors by overlining with a fluomarker, which then could form the basis of a negotiated solution between researcher and corrector. When the moment of realisation arrives, it is made to be memorable. This technique is valid across the board for all kinds of errors, and has the merit of drawing attention not so much to descriptions of language but to the way it functions. Personally, I have found that the vast majority of researchers simply do not need such descriptions: once seen, once learnt, provided the language features concerned are written down in a small exercise book representing the ongoing sum total of the particular researcher's needs and shortcomings within the genre. Moreover, these items, although common to many French researchers as if there was a common core of unknown or poorly acquired language elements, cannot be learnt in any set order. Indeed, many are extrapolated autonomously, in the absence of any teacher or corrector.

Third, instead of setting out to teach the hypothetical paradigmatic structure of the research article, it might be preferable to ask the researcher to bring to the meeting a set of "Instructions to Authors" and published articles from the particular journal in which he intends to publish his work. Even brief comparison of three or four sets of these documents shows an identical overall paradigmatic structure to be wanting from one journal to the next, despite many common features. So criticisms such as "You've put this result in the method" require some mitigation, since it may just be that this is acceptable in that particular journal. John Swales nicely summarizes the situation when linguists meet specialists of other discourse communities on the latter's ground:

... there are certain limits to what we can do and hence areas where we should fear to tread. (Swales 1990)

Until now I have argued for an individualised approach to the fully-fledged researcher's writing requirements. Using the 'real thing' and pedagogically exploiting its weaknesses probably offers the greatest benefit to the busy research worker, since the correcting linguist is able to go straight to the heart of the matter. Yet this does not preclude language teaching resources being allotted to doctoral students, for this would indeed be a good investment for the future. After all, many of today's researchers learnt the English of their specialty purely by their own hard work and intelligence, frequently without any linguistic guidance at all at this level. If reading comprehension were to be improved upstream, this would save valuable corrector-hours later on.

31 What might be done is this. A group of twelve highly motivated doctoral students of different specialties (but within the sciences) could meet on a regular basis for mutual assistance in reading documents they themselves would provide. I would insist on 'within the sciences' since in a group of highly educated young scientists, it is unlikely that there 
would be much interdisciplinary mutual misunderstanding. Mutual comprehension of the main concepts in each other's articles is a prerequisite for what follows (Fig.4).

Figure 4: Doctoral students: possible management of reading class; pedagogic strategies for correcting articles

\begin{tabular}{|l|l|}
\hline 0 & GROUP = TWELVE HIGHLY MOTIVATED STUDENTS OF DIFFERENT SPECIALTIES \\
\hline 1 & DISCUSS WHAT SECTION TO DEAL WITH: THEN (PAIRS) BLACK-BOX UNKNOWN ITEMS \\
\hline 2 & SWAP FOR MUTUAL HELP \\
\hline 3 & INDICATE REMAINING DIFFICULTIES TO TEACHER WHO MAKES PHOTOCOPIES \\
\hline 4 & DISCUSSION IN FOURS \\
\hline 5 & TIME FOR READING AND ASSIMILATION \\
\hline 6 & MUTUAL ASSISTANCE WITHIN QUARTET (TEACHER OUTSIDE) \\
\hline 7 & FINAL GROUP DISCUSSION LED BY TEACHER \\
\hline 8 & TIME FOR RECORDING FINDINGS \\
\hline
\end{tabular}


temptation of bringing them straightaway back to what I might feel to be more pressing matters, because they themselves would inevitably hierarchise these problems later on.

Indeed, at some later date, it might well be possible for the participants to work without a teacher being physically present at all, such being the progress constantly made in desktop services. And the ongoing record of the reading comprehension difficulties of at least four peers can only be beneficial.

Swales (1990) discusses several advantages that derive from introducing rhetorical structure as a central element in a course. I would add two more associated with having a $100 \%$ Francophone class. First, it is motivating and reassuring for participants to realise that far from being underperformers in English, they may well experience exactly the same problems as their colleagues. There seems to be a corporate Francophone knowledge of English with many common gaps, probably due to language transfer. Secondly, in-class discussion can take place in French so may be richer.

In general, it would seem that while fully fledged researchers require individualisation, doctoral students require more this sort of semi-diagnostic approach. As for students to Masters level and although they are not the central preoccupation here, a good functional reference book such as that by Upjohn, Blattes and Jans (1991) would provide a sound basis for acquiring "minimum competence in scientific English".

I would like to conclude with a few remarks on our present situation.

First, since we ESP teachers are now finding ourselves increasingly at a unique interface between our own know-how and that of researcher colleagues on whom the pressure to publish in English is overwhelming, we must develop rational cost-effective strategies for helping such colleagues.

Second, "the proof of the pudding is in the eating". We are fulfilling one of our tasks when a paper gets published or when reviewer criticism no longer concerns the English per se. However, unless expressly asked to do so, it is not really for us to intervene in the rhetorical decision-making process regarding structural organisation of content. This is the author's task.

Third, being able to help with this genre is a most rewarding intellectual experience, providing as it does a tangible overview of state-of-the-art developments in the fields covered by people one would otherwise never meet.

Fourth, this role is a vital and somewhat misunderstood one. If we can sensitize researchers, and more importantly the decision-makers above them, to the need for such work and for it to be considered at its true value, then our profession will have taken a step forward. English is the immutable vehicle for scientific and technical communication both in the present world and the foreseeable future, and the words of Maurice Allais, Nobel Prize winner a few years ago, still ring true.

Les anglophones ne doivent pas avoir le monopole du savoir. 


\section{BIBLIOGRAPHY}

Altman, H. and C. Vaughn James. 1980. Foreign language Teaching: Meeting Individual Needs. Oxford: Pergamon.

Hutchinson, T. and A. Waters. 1987. English for Specific Purposes: A learning-centred approach. Cambridge: Cambridge University Press.

Odlin, T. 1989. Language Transfer. Cambridge: Cambridge University Press.

Swales, J. 1990. Genre Analysis. Cambridge: Cambridge University Press.

Trimble, L. 1985. English for Science and Technology. Cambridge: Cambridge University Press.

Upjohn, J., S. Blattes and V. Jans. 1991. Minimum Competence in Scientific English. Grenoble: Presses Universitaires de Grenoble.

\section{AUTHOR}

\section{RAY COOKE}

DLVP Université Bordeaux 2. ray.cooke@u-bordeaux.fr 